\title{
Speleogenetic effects of interaction between deeply derived fracture-conduit flow and intrastratal matrix flow in hypogene karst settings
}

\author{
Alexander Klimchouk ${ }^{1}$, Elizaveta Tymokhina ${ }^{1}$, and Gennadiy Amelichev ${ }^{1}$
}

\begin{abstract}
:
Klimchouk A.B., Tymokhina E.I. and Amelichev G.N. 2012. Speleogenetic effects of interaction between deeply derived fracture-conduit flow and intrastratal matrix flow in hypogene karst settings. International Journal of Speleology, 41(2), 161-179 Tampa, FL (USA). ISSN 0392-6672. http://dx.doi.org/10.5038/1827-806X.41.2.4

In carbonate rocks, especially in those with high primary porosity such as most Cenozoic carbonates, the interaction between deeply derived rising flow through sub-vertical fracture-controlled conduits and intrastratal matrix flow of shallower systems can invoke mixing corrosion and result in prominent speleogenetic effects. This paper outlines a conceptual model of such interaction and provides instructive field examples of relevant morphological effects from two different regions within the Prichernomorsky (north Black Sea) basin, where karst features are developed in lower Pliocene, Eocene and Paleocene limestones. In the Crimean fore-mountain region, extensive steep to vertical limestone scarps formed through recent exposure of hypogenic fracture-controlled conduits provide outstanding possibilities to directly examine details of the original karstic porosity. The morphological effects of the conduit/matrix interaction, documented in both caves and exposed scarps, include lateral widening of sub-vertical conduits within the interaction intervals (formation of lateral notches and niches) and the development of side bedding-parallel conduits, pockets and vuggy-spongework zones. Natural convection circulation, invoked by interaction of the two flow systems, spreads the morphological effects throughout the conduit space above the interaction interval. Where the interaction of the two flow systems is particularly strongly localized, such as along junctions of two vertical fracture sets, the resultant morphological effect can take the form of isolated chambers. The variety of speleogenetic features developed through the conduit/matrix interaction, can be broadly grouped into two categories: 1) variously shaped swells of the major fracture conduit itself (morphological features of its walls - niches and pockets), and 2) features of the vuggy-spongework halo surrounding the conduit. This halo includes clustered and stratiform cavities, spongework zones and lateral side conduits. The speleogenetic features due to conduit/matrix flow interaction, especially the halo forms, often demonstrate distinct asymmetry between opposite walls of the conduits. The prominent phenomenon of the vuggy-spongework halo around fracture-controlled conduits has important hydrogeological implications. A comparison of karst features in different regions and rock formations clearly shows that in spite of some distinctions imposed by local structural, sedimentological and paleo-hydrogeological peculiarities, hypogenic speleoforms in limestones of different age and of different degree of diagenetic maturity demonstrate remarkable similarities.
\end{abstract}

Keywords: multiple porosity systems; conduit/matrix interaction; hypogenic speleogenesis; Cenozoic carbonates; north Black Sea; Odessa; Crimea

Received 9 December 2011; Revised 20 January 2012; Accepted 20 January 2012

\section{INTRODUCTION: POROSITY TYPES, PERMEABILITY SYSTEMS AND THEIR INTERACTION}

Karst aquifers are characterized by complex heterogeneous distribution of different types of porosity including various types of pores and micro-fractures within the matrix rock, fractures along joints, faults and bedding planes, and conduits (cavities) enlarged by dissolution. Karst conduits are dissolution features with apertures exceeding 10-15 mm,

${ }^{1}$ Ukrainian Institute of Speleology and Karstology, Simferopol, Ukraine (klim@speleogenesis.info) sometimes reaching meters and tens of meters. While many pores represent the primary porosity, fractures are treated in sedimentology as secondary features. As solution conduits develop through enlargement of pre-speleogenetic openings in the rocks, mainly fractures but also interconnected pores or both, they can be treated as the tertiary porosity structures. This complex porosity origin and distribution determines major aquifer characteristics, such as storage and flow (Worthington, 1999).

Depending on geologic (burial) history of a host formation and karst evolution (Klimchouk \& Ford, 2000a, b; Vacher \& Mylroie, 2002), the above elementary porosity structures in soluble rocks may be represented to a different extent, and constitute more or less 
contrasting and independent permeability systems. Depending on the expression of these porosity types, their connectivity and the contrast between them, and also on research aims and means, karst aquifers are conceptualized as dual (commonly), triple or even more complicated porosity/permeability systems.

The main types of elementary porosity structures can be further subdivided or variously combined into relatively homogenous porosity/permeability systems, distinguishable in a given geological setting. Large aperture mechanical fractures and fractures enlarged by dissolution are commonly placed into the conduit category, which elements are considered as discrete features. Unmodified fractures along joints, faults and bedding planes can be distinguished as another system, with discrete or homogenous distribution, depending on the scale of consideration. From the perspective of groundwater flow, small fractures (micro-fractures) and pores often behave as a single system and are commonly combined into the category of matrix porosity. In different geological settings, matrix porosity can be pore-dominated, such as in young eogenetic limestones, or fracture-dominated, such as in some dolomites or chalks.

Following the main porosity types, permeability in karst aquifers is generally characterized by a triple structure, with channels (conduits), fractures (joints and bedding planes), and matrix pore systems differing from each other in two-three orders of magnitude (Worthington, 1999; Worthington et al., 2000). Conduits by far dominate flow but matrix porosity elements account for most of storage.

The notion of multiple porosity, originally suggested by Barenblatt et al. (1960) and applied to karst aquifer characterization by Borevsky et al. (1973, 1976), has been widely used during last two decades to conceptualize and simulate groundwater flow, solute transport and conduit development in karst aquifers, as well as the evolution of an aquifer as a whole (e.g. Sauter, 1993; Groves \& Howard, 1994; Clemens et al., 1996; Kaufmann \& Braun, 1999; Worthington, 1999; Sauter \& Liedl, 2000; Bauer et al., 2003; Liedl et al., 2003; Dreybrodt et al., 2005; Shoemaker et al., 2008). In speleogenesis modeling studies, karst aquifers are commonly conceptualized as a dual system, in which the bulk mass of a soluble rock is represented by a continued pore and/or fracture "diffuse" system, and the karst network is represented by a discrete conduit system. The two systems are distinctly different in their hydraulic and solute-transport properties. They interact by the exchange of water and solutes in response to gradients in fluid pressure and solute concentration. In modeling, the two systems are coupled via linear steady state exchange terms at the network intersections, i.e. the exchange rate is assumed to be proportional to the head difference between the flow systems and the exchange coefficient. The conduit walls between the network intersections are assumed to be impenetrable (no-flow boundary), and dissolution is assumed to occur along the walls. In reality, however, the matrix-conduit water exchange occurs, although unevenly, along the whole surface of the conduit walls.
Although conduit development in karst aquifers is commonly guided by fractures and partings, the interaction between matrix and evolving conduits can influence how these conduits enlarge over time. Hydraulic and chemical interaction between the conduit and matrix porosity/permeability systems has been accounted for in the modeling of the early development of conduits and shown to be significant for it (see the above cited works). Romanov et al. (2002) suggested that dissolution in the matrix (fissured) system is negligible if the openings of fractures in the matrix system are smaller that initial diameters of the conduit system and if the overall hydraulic gradient is smaller than 1.0. However, the influence of the interaction between these systems on morphogenesis of mature conduits and on the matrix porosity development around conduits, have been poorly studied.

In rocks that retain high matrix porosity and permeability (i.e., in relatively young rocks that have not experienced deep and prolonged burial) exchange between the conduit and matrix pore media can be significant, as demonstrated by recent publications for the Floridan Aquifer (e.g. Martin \& Dean, 2001; Budd \& Vacher, 2004; Florea \& Vacher, 2007; Moore et al., 2010). These works have focused on unconfined or shallow confined portions of the regional flow systems, where contribution of allogenic surface recharge directly to the conduit system is substantial, resulting in high variations in hydraulic heads in conduits and hence variable head gradient and water exchange between the two media. From studying temporal and spatial variations of the chemical composition of water in sinking surface streams, springs (conduit flow) and wells (matrix flow) in the Floridan aquifer, Martin \& Dean (2001) have shown the exchange of water between matrix and conduits. The significant loss of water from the conduits to the matrix occurs during high stage of recharging surface streams. Moore et al. (2010) studied dissolution effect of aggressive water inflow from the conduit to matrix during high stage of surface rivers and suggested that a higher porosity halo should form around conduits due to this process. Such halo, in fact, has been reported from field observations in caves in Florida (Florea, 2006).

However, a higher porosity halo around conduits and distinct regular features in the conduit morphology can also form in deep-seated confined settings due to the mixing corrosion effect of the interaction between deeply derived rising flow through sub-vertical fracture-controlled conduits and lateral intrastratal matrix flow of shallower systems. In this paper we develop a conceptual model for such interaction and provide instructive field examples of relevant morphological effects from two different regions within the Prichernomorsky (north Black Sea) basin: the Odessa region, with karst features developed in lower Pliocene limestones, and the Crimean foremountain region, with karst features developed in Eocene and Paleocene limestones. 


\section{HETEROGENEITY OF THE MATRIX POROSITY AND PERMEABILITY}

Evaporites and mature (telogenetic) carbonates normally have low matrix permeability and most flow is transmitted through fractures, with still greater concentration in conduits when they evolve. Relatively young diagenetically immature carbonate rocks (eogenetic) that have not been deeply buried, such as most of Cenozoic limestones, tend to exhibit greater pore matrix permeabilities than telogenetic rocks that have undergone extensive pore cementation and compaction and hence have generally lesser pore matrix permeability. Budd \& Vacher (2004) demonstrated, using globally distributed examples of karst aquifers, that Cenozoic carbonates have matrix permeabilities two to four orders of magnitude greater than Paleozoic and Mesozoic rocks.

From the perspective of flow pattern and speleogenesis, however, heterogeneities within a given rock succession are more important than overall permeability differences between eogenetic and telogenetic rocks. Carbonate rocks, with their highly varied sedimentary textures and structures and layered differences in post-depositional alteration (Choquette \& Pray, 1970; James \& Choquette, 1984; Sholle et al., 1983), often demonstrate distinct layered heterogeneity in primary porosity and permeability. A number of studies demonstrate that the distribution of porosity and permeability relates closely to lithofacies, so that cyclostratigraphy is increasingly used for characterization of vertical heterogeneity of porosity and permeability (e.g. Hovorka et al., 1998; Budd \& Vacher, 2004; Cunningham et al., 2006).

Budd \& Vacher (2004) show that matrix permeability in Cenozoic (Eocene and Oligocene) eogenetic carbonates in the Upper Floridan Aquifer is extremely heterogeneous, ranging over three orders of magnitude between different lithofacies (from $<10^{-14.4}$ to $10^{-11.1} \mathrm{~m}^{2}$ ). They have demonstrated that the magnitude of water exchange between porous blocks and fracture conduits is also facies-controlled, and the matrix-conduit hydraulic interaction is extremely important in the more highly permeable facies. Cunningham et al. (2006) developed a highresolution cyclostratigraphic model for the carbonate Biscayne Aquifer, Florida (upper Pliocene through Pleistocene limestones), and demonstrated pronounced regular variations in porosity structure and permeability between lithofacies (specific beds), arranged in cyclic successions of three types. Permeability of the aquifer is heterogeneous by layers, with values differing up to two orders of magnitude between the lithofacies. They found that much of the subsurface karst porosity and groundwater flow in the Biscayne Aquifer is closely related to stratigraphic cycles. Three types of highly permeable stratiform flow zones, interbedded with low-permeability zones are recognized. Similar examples of pronounced facies-dependent layered heterogeneity within the same carbonate unit are given in Vacher \& Mylroie (2002) and in many other works.

Despite of generally lower matrix pore permeability, older telogenetic carbonate successions may also have distinct layered facies-controlled heterogeneity (e.g. Hovorka et al., 1998). In addition to the variations in matrix porosity due to intergranular and intercrystalline pores, which are generally lesser than in eogenetic rocks, telogenetic rocks often have pronounced differences in the distribution and abundance of cross joints (those contained within one or a few beds) between beds or series of beds as a function of lithology, facies and thickness of beds. Considered as a single system (in contrast to master joints, faults and conduit systems), such pore/micro-fracture porosity, or layer-confined fracture porosity, frequently accounts for variations in permeability between layers within carbonate successions up to two or three orders of magnitude.

Superimposed on the rock matrix are fractures along joints, faults and bedding planes. Bedding plane fractures or fractured beds in telogenetic rocks, and highly permeable porous intervals and touching-vug systems in eogenetic rocks (Lucia, 1995; Vacher \& Mylroie, 2002), provide for lateral stratiform zones of preferential flow in layered successions. Networks of vertical fractures encased in single beds (more common in telogenetic rocks) provide for vertical communication between adjacent stratiform permeability elements. Conduits, controlled by larger master joints or faults penetrating though several or many beds, provide for cross-formational flow that may originate from a wholly different hydrodynamic system.

There can be various combinations of layered and cross-formational heterogeneities within a given (cave-hosting) soluble sequence and adjacent sequences determining the initial (pre-speleogenetic) permeability structure and a framework of percolating pathways.

\section{A CONCEPTUAL MODEL}

For field areas referred to in this paper, the hydrogeological structure can be conceptualized as a confined layered aquifer system with limestone formations consisting of facies-controlled hydrostratigraphic units and interfaces of contrasting matrix porosity and permeability. More permeable units conduct diffused lateral intrastratal laminar flow. The system is penetrated by discrete sub-vertical master fracture conduits that are highly permeable paths conducting rising, deeply derived flow (Fig. 1).

The conduits and porous matrix constitute the two media with different sources of fluid potential. The hydraulic interaction between these media is determined by head gradients and the contrast of permeability between them.

Following Eichhubl \& Boles (2011), we subdivide cross-formational fracture conduits into three hydraulic regimes according to a mode of their interaction with the formation-parallel matrix conductive horizons: 1) source regions, where matrix fluid is drawn into the conduit from the surrounding matrix media of higher hydraulic head (SO in Fig. 1); 2) sink regions, where conduit fluid is pushed into the matrix media of lower hydraulic head or onto the Earth's surface (SI), and 3) intermediate neutral regions where no significant fluid exchange occur between the conduit and the matrix $(\mathrm{N})$. 


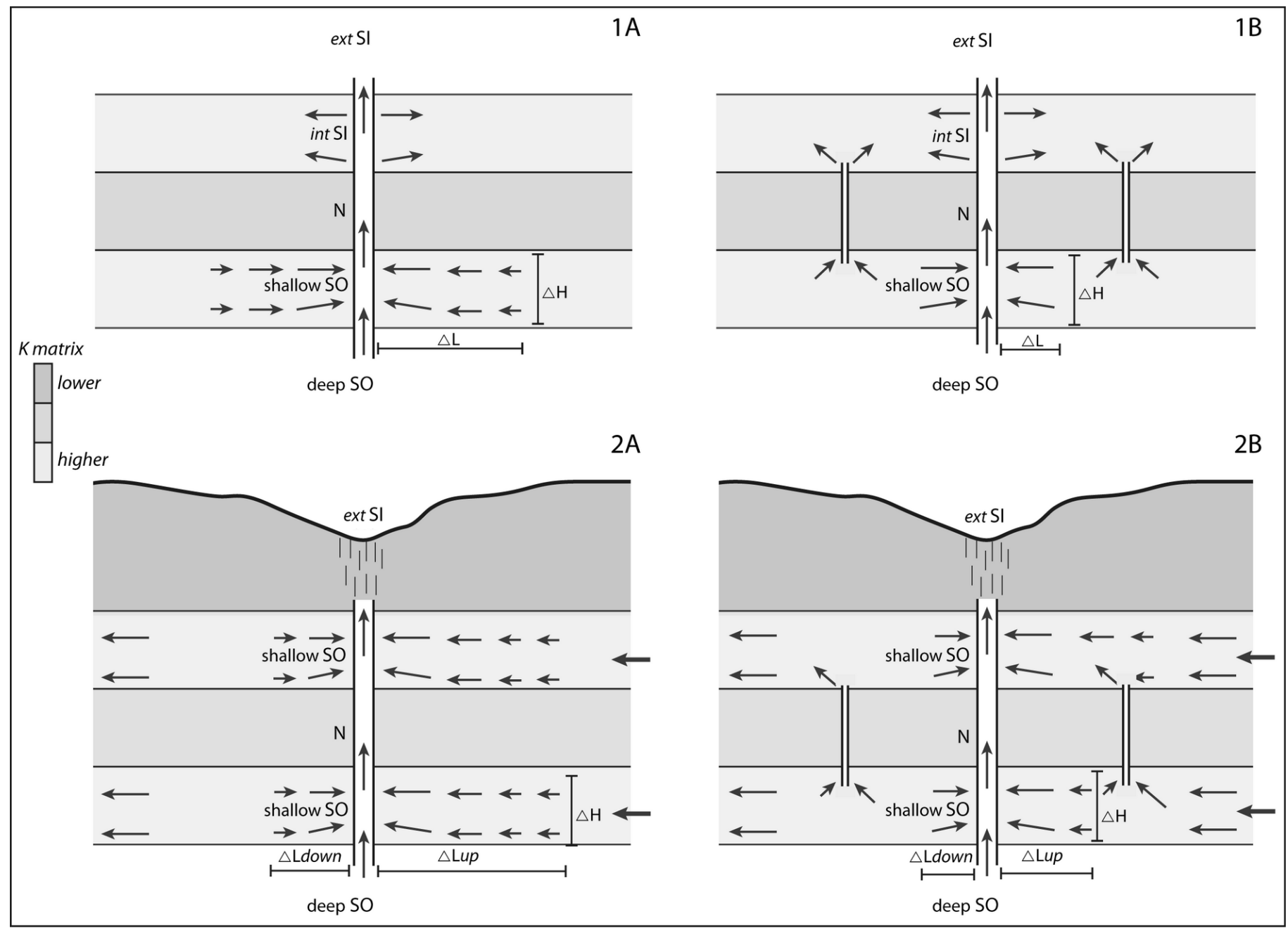

Fig. 1. Hydraulic regimes in cross-formational fracture conduits according to a mode of their interaction with the formation-parallel matrix conductive horizons, and flow patterns under different boundary conditions. Upper row (1A, 1B): in deep-seated confined settings, where hydraulic communication with an external major sink region (e.g. the Earth surface) is weak. Regional flow in the aquifers is perpendicular to the view; Lower row (2A, 2B): in shallower leaky confined settings, where hydraulic communication with an external major sink region is strong. Regional flow in the aquifers is right to left; Columns: A - strong anisotropy; B - weak anisotropy. SO - source regions (deep SO and shallow SO). SI - sink regions: int SI - internal; ext SI - external. N - neutral regions. $\Delta \mathrm{L}$ - zone of hydraulic influence of the conduit: $\Delta$ Lup - on the upgradient side; $\Delta$ Ldown - on the downgradient side. Adapted from Eichhubl \& Boles (2011).

The differences in hydraulic heads between the conduit and matrix in the aquifers can be maintained due to different sources of the fluid potential. The differences in hydraulic heads between the aquifers are due to different boundary conditions. In deep-seated confined settings temporal pressure variations in the two media are negligible so that flow exchange between them should be at steady-state, being either source or sink type (Fig. 1, upper row). The pressures in the different media can be also equilibrated in some regions of the conduit where no exchange occurs (neutral regions).

When the sequence is being brought into shallower position due to tectonic uplift and denudation, leakage from the confined system increases due to thinning and local breaching of the capping formations. The leakage occurs mainly through the highpermeability cross-formational paths such as subvertical master fracture conduits. Decrease of the hydraulic head in the conduit makes it acting as a low-resistance drain that draws matrix groundwater to converge on it, so that the source region regime becomes dominating along the cross-formational conduit (Fig. 1, lower row).

Within the source region, inflow of the intrastratal matrix water into the conduit through the conduit/ matrix boundaries (conduit walls) is equivalent from the opposite sides when the conduit is aligned with the regional flow direction in the aquifer (upper row diagrams in Fig. 1), provided other conditions are equal. The matrix inflow from the sides is not equal when conduits are oriented at an angle to the regional flow direction, with more matrix water contributing from the up gradient side than from the down gradient side (lower row in Fig. 1). The formation-parallel propagation of the zone of hydraulic influence of the conduit $(\Delta \mathrm{L})$ will be greater into the up gradient side than into the down gradient side. Volumetric influx of the matrix water from the up gradient side will be greater. The presence of conduits en echelon on the up gradient side can diminish inflow to a given conduit from this side (2B in Fig. 1). 
A

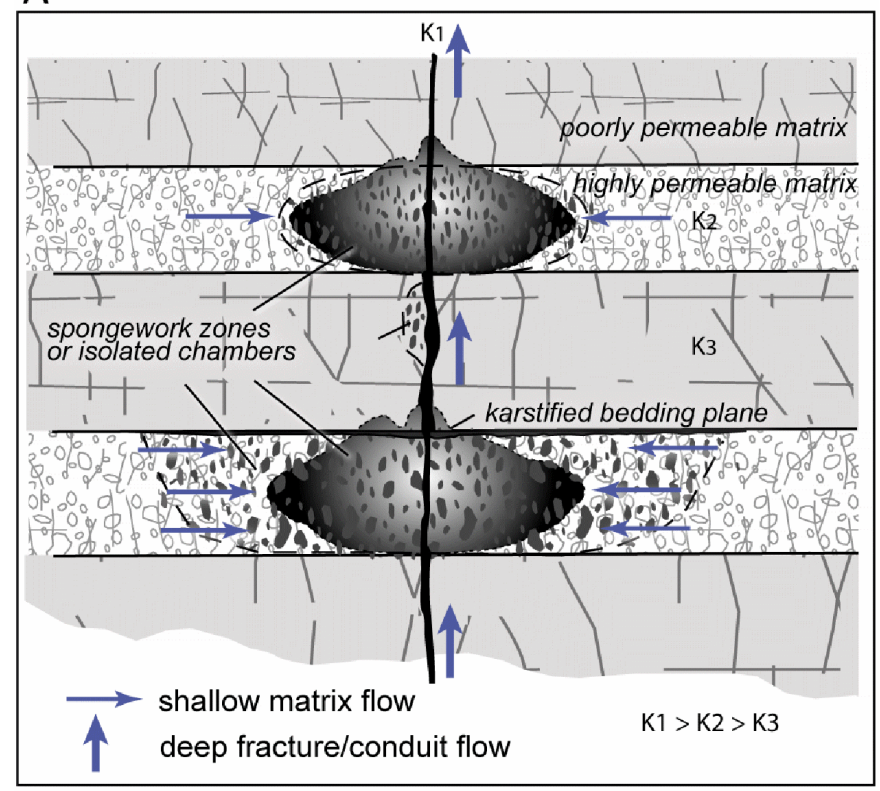

$\mathrm{B}$

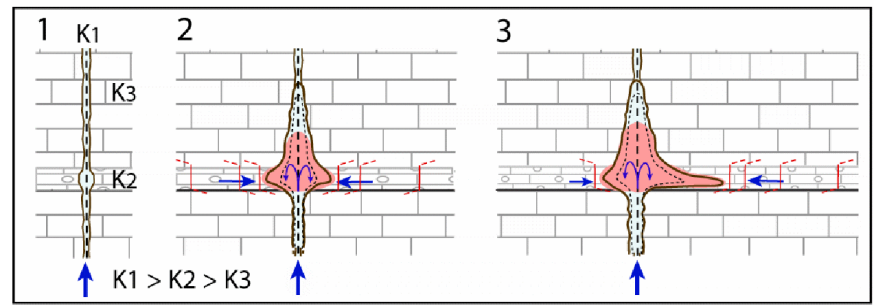

Fig. 2. Conceptual representation of morphological effects due to interaction between deeply derived conduit flow and shallower formation-parallel matrix flow . A - formation of "spongework zones" and/or isolated chambers, B - symmetric (2) and asymmetric (3) widening of an original fracture conduit (1) along its intersection with a bed of high matrix porosity and permeability.
In limestone sequences under confined conditions, water in both stratified aquifers transmitting lateral flow and sub-vertical master fracture conduits transmitting rising deep flow is expected to be saturated and hence nonaggressive with respect to calcite because of its long residence time. However, the waters in the two media can be of contrasting chemistry, differing in $\mathrm{CO}_{2}$ or $\mathrm{H}_{2} \mathrm{~S}$ content or salinity, so that the interaction of the conduit and matrix waters renews solutional aggressiveness with respect to calcite, the effect widely referred to in the karst literature as mixing corrosion (Laptev, 1939; Bögli, 1964; Palmer, 1991; Dreybrodt et al., 2005).

The intensity of dissolution due to mixing depends on the mixing ratio between the waters. The location and configuration of the zone of the renewed aggressiveness depends on the relationship of volumes of the two mixing waters, their flow regimes, the conduit wall relief and the geometry of the initial pore system, the contrast in permeability between the two media, and the thickness of the interval of enhanced matrix permeability. Differences in salinity and/or temperature between the waters can cause convection effects to operate, which also influences dissolution pattern. The aggressiveness zone can extend down gradient (upward) along the conduit wall, but should also encompass some pore space at the vicinity of the wall, particularly in case of young porous limestones. With enlargement of pore apertures in the immediate vicinity to the wall, the pore space is increasingly occupied by the conduit water, so that the aggressiveness zone progressively retreats deeper into the matrix block causing pore enlargement there.

The interaction between deeply derived fractureconduit flow and intrastratal matrix flow, localized at intervals where conduits intersect with highly permeable layers and bedding planes, should result in expressed morphological effects (Fig. 2). These effects include widening of conduits within the interaction
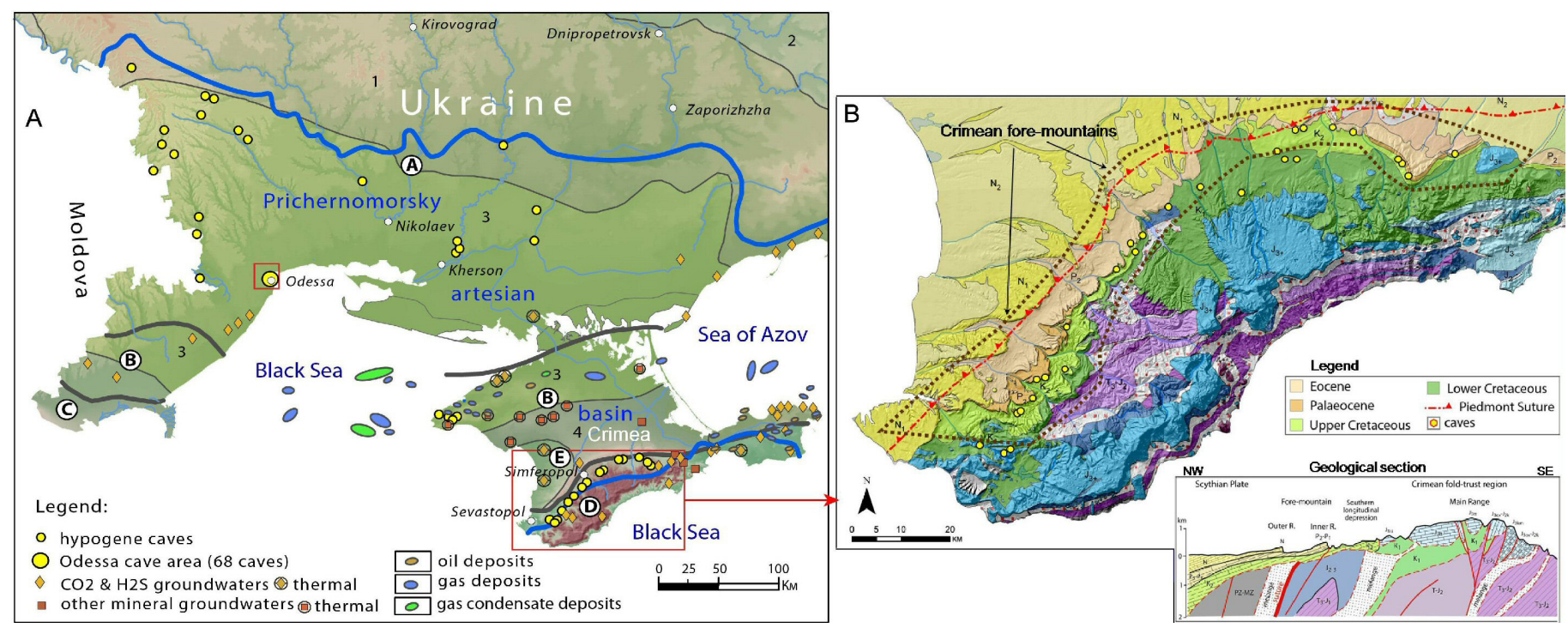

Fig. 3. A - Hypogene caves and relevant hydrogeologic features in carbonate successions of the Prichernomorsky artesian basin, South Ukraine. Major tectonic structures (circled characters): A - Eastern-European Platform (pre-Rifean); B - Scythian Plate (epi-Paleozoic); C North Dobrogea fold-thrust region (Hercynian); D - Crimean foulded region (Kimmerian-Alpine); E - Crimean foredeep (Kimmerian-Alpine). Other tectonic structures: 1 - Ukrainian Shield; 2 - Dnieper-Donetzk Depression (Mesozoic); 3 - Prichernomorsky Depression (CretaceousPaleogene); 4 - Central-Crimean Uplift (Cretaceous-Paleogene). B - Geologic map of the southwest part of the Crimean Peninsula and schematic geologic profile after Yudin, 2009. 

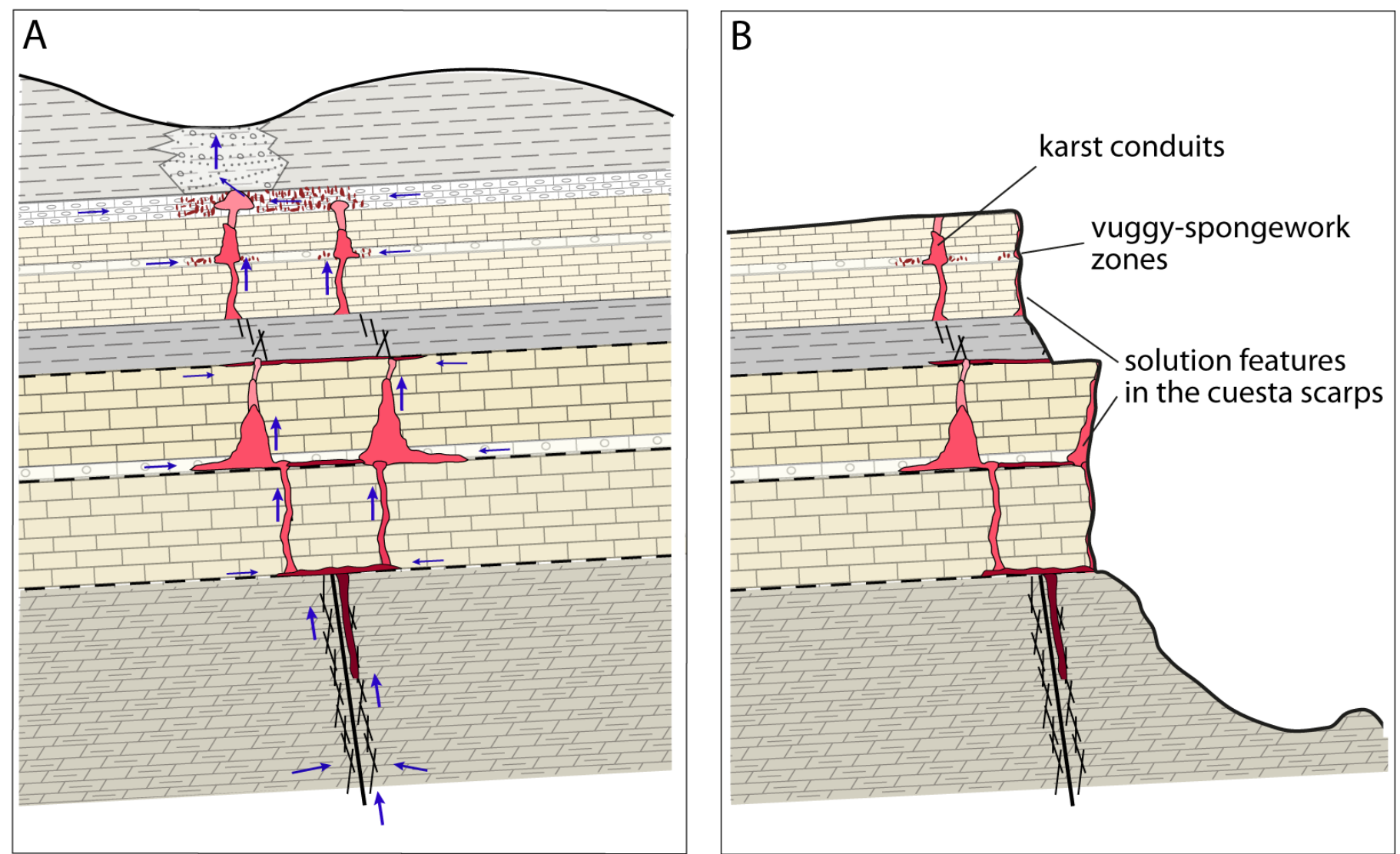

Fig. 4. Conditions of the formation (A) and the current geomorphic situation (B) of caves and other karst features in the Inner Range of the Crimea fore-mountains.

interval (formation of lateral notches and niches), formation of side bedding-parallel conduits and pockets, and vuggy (spongework) zones. When the interaction of the two systems is particularly strongly localized due to intersection of their respective preferential flow structures, the resultant morphological effect can take form of an isolated chamber.

In the following sections we shall demonstrate various representations of these morphological effects in Cenozoic limestones in the study regions of the Prichernomorsky artesian basin.

\section{STUDY REGIONS}

The study regions are situated in different parts of the Prichernomorsky artesian basin, a major hydrogeological structure of the north Black Sea region. The basin occupies the south part of the continental Ukraine and the north-central plain part of the Crimea Peninsula (Fig. 3). It is dominated by the Cenozoic carbonate rocks, intercalated with sands, sandstones, clays and marls.

The key regions for this study, where some limestone members are exposed and partially drained, lay in the opposed sides of the basin. The Odessa region is in the continent, within the Eastern European Platform. Caves occur there in almost horizontally lying upper Miocene and lower Pliocene limestones. In the southern edge in Crimea, the basin borders with the Crimean Mountains (the Alpine fold-thrust region) and includes the cuesta-like Outer and Inner Ranges of the Crimean fore-mountains (Fig. 3 B). Along the Inner Range, the Neogene rocks are eroded away and Paleocene and Eocene limestones are uplifted and tilted at 5-20 degrees to north - north west. This is a second key region for this study.

Karst in the Prichernomorsky artesian basin has been previously interpreted in the framework of the traditional epigenic paradigm, with deep-seated features regarded as paleokarst. Recent studies, however, strongly suggest that hypogene speleogenesis is the region-wide process responsible for the formation of conduits, caves and vuggy (spongework) zones. Karst features are presently relict in the areas where limestones are uplifted and drained, and still develop in the central confined part of the basin, where they account for some distinct hydrogeological and geochemical features of the regional multi-story aquifer system (Klimchouk et al., 2009, 2011a).

In the Odessa region, the lower Pliocene (Pontian) limestones that host caves have generally high but varying matrix porosity (commonly within 30$50 \%)$. The limestone bed is covered by the upper Pliocene red-brown clays of low permeability and the Pleistocene succession of loams and loesses. The limestone is exposed only in scarps along the Black Sea, where outcrops are severely reworked by coastal morphodynamics and landslide processes, and in some large ravines. Numerous caves and karstified fractures that have no connection to the surface are intercepted by extensive ancient underground mines beneath the city of Odessa.

The Inner Range of the fore-mountain Crimea is an arcwise series of northwest-inclined cuesta-like massifs stretching for about $140 \mathrm{~km}$, parallel to the Crimean Mountains to the north-north-west (Fig. 3 B). The range is aligned to a regional tectonic su- 
ture, a junction between the Crimean fold-thrust region and the Scythian Plate. The cuesta massifs are armored by the dipping beds of Eocene and Paleocene limestones. Matrix porosity of the Eocene limestones varies in a wide range, with layer-specific values 5-10 $\%, 15-17 \%$ and $25-30 \%$ (Lygina, 2010). Matrix porosity of the Paleocene limestones is also variable within 5-20\% (sometimes up to $40 \%$; Gorbach, 1964).

The cuesta massives are separated by trunk river gorges crossing the Inner Range. Smaller valleys with steep to vertical sides, often with pocket heads, are incised into the limestone beds on the inclined structural slope of the cuesta massifs. The limestone beds are exposed as distinct scarps along the overall cuesta front and sides of consequent valleys, displaying various hypogenic karst features (Fig. 4). The total length of limestone outcrops in scarps is roughly estimated to be over $500 \mathrm{~km}$. A recent study based on $\mathrm{U} / \mathrm{Th}$ dating of phreatic and vadose speleothems from hypogenic caves in the south-west sector of the range (Klimchouk et al., 2011b) suggests that the front scarp of the Paleocene cuesta has been incised and exposed during the second half of Middle Pleistocene.
Another recent study (Tymokhina et al., 2011) has demonstrated that the incision and further evolution of valleys in the structural slope of the Eocene and Paleocene limestones was strongly guided by hypogenically karstified, 100-400 m wide linear zones of intense fracturing. The ongoing block-fall retreat of limestone scarp faces exposes karstified fractures and cavities in marginal parts of these zones along sides of today's valleys, which accounts for abundance of specific solution morphologies displayed in the scarps. Observations in limestone quarries located on the structural slope of the cuestas suggest that fractures are rare and non-karstified in interior parts of the massifs, away from the valleys.

The main speleogenetic process in both regions, clearly discerned from hydrostratigraphic/ structural relations and the morphology of caves and other karst features, is renewal of aggressiveness due to mixing of deep vertical and shallow lateral flow in the confined aquifer system. Dissolution by rising thermal waters and by sulfuric acid (due to oxidation of $\mathrm{H}_{2} \mathrm{~S}$ ) is also likely to have played a role, at least locally, particularly in the Crimean fore-mountains.

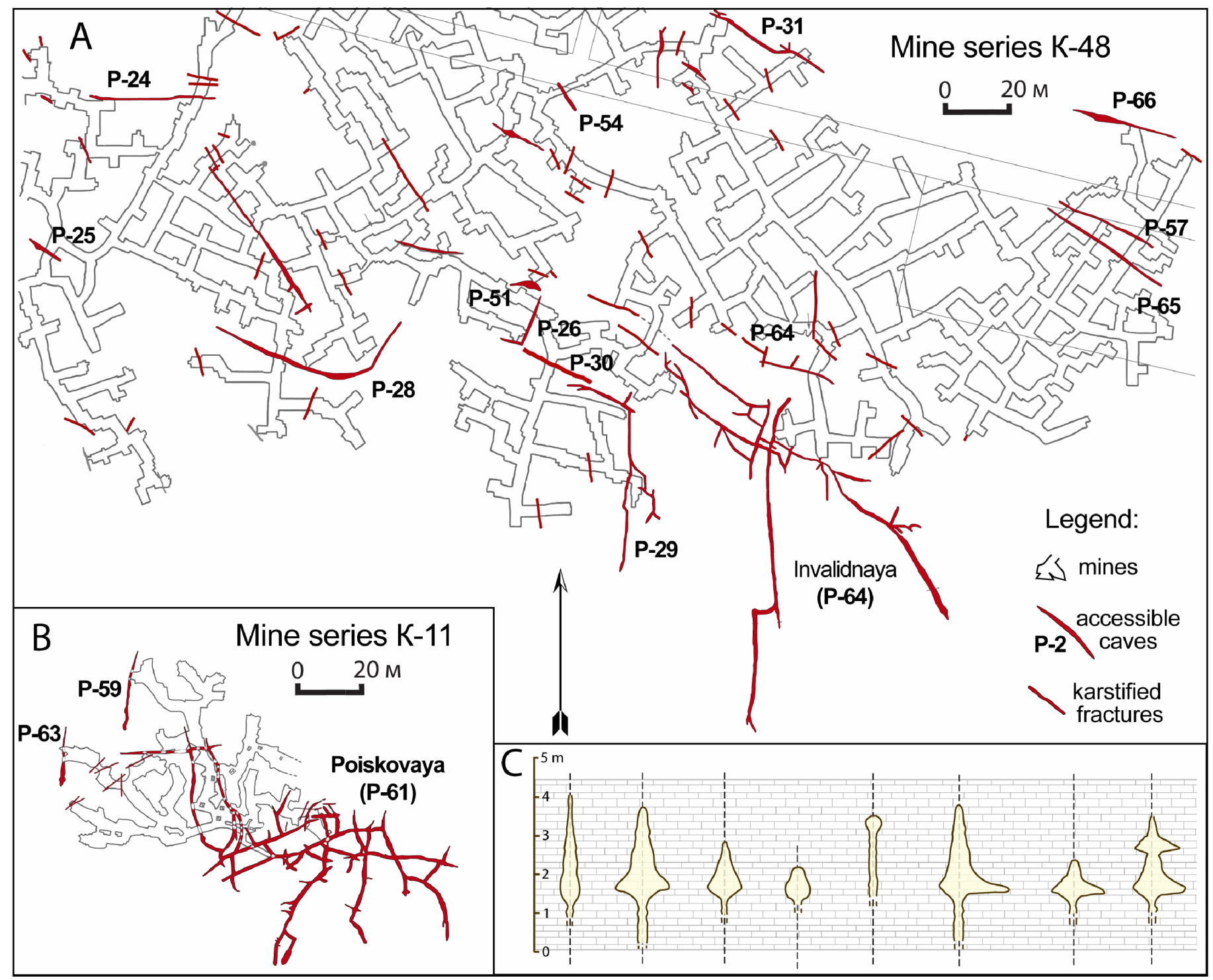

Fig. 5. Distribution of caves and karstified fractures (red lines) intercepted by ancient mines (grey lines) in the lower Pliocene (Pontian) limestones in the Odessa region, south Ukraine (from Klimchouk et al., 2010). 

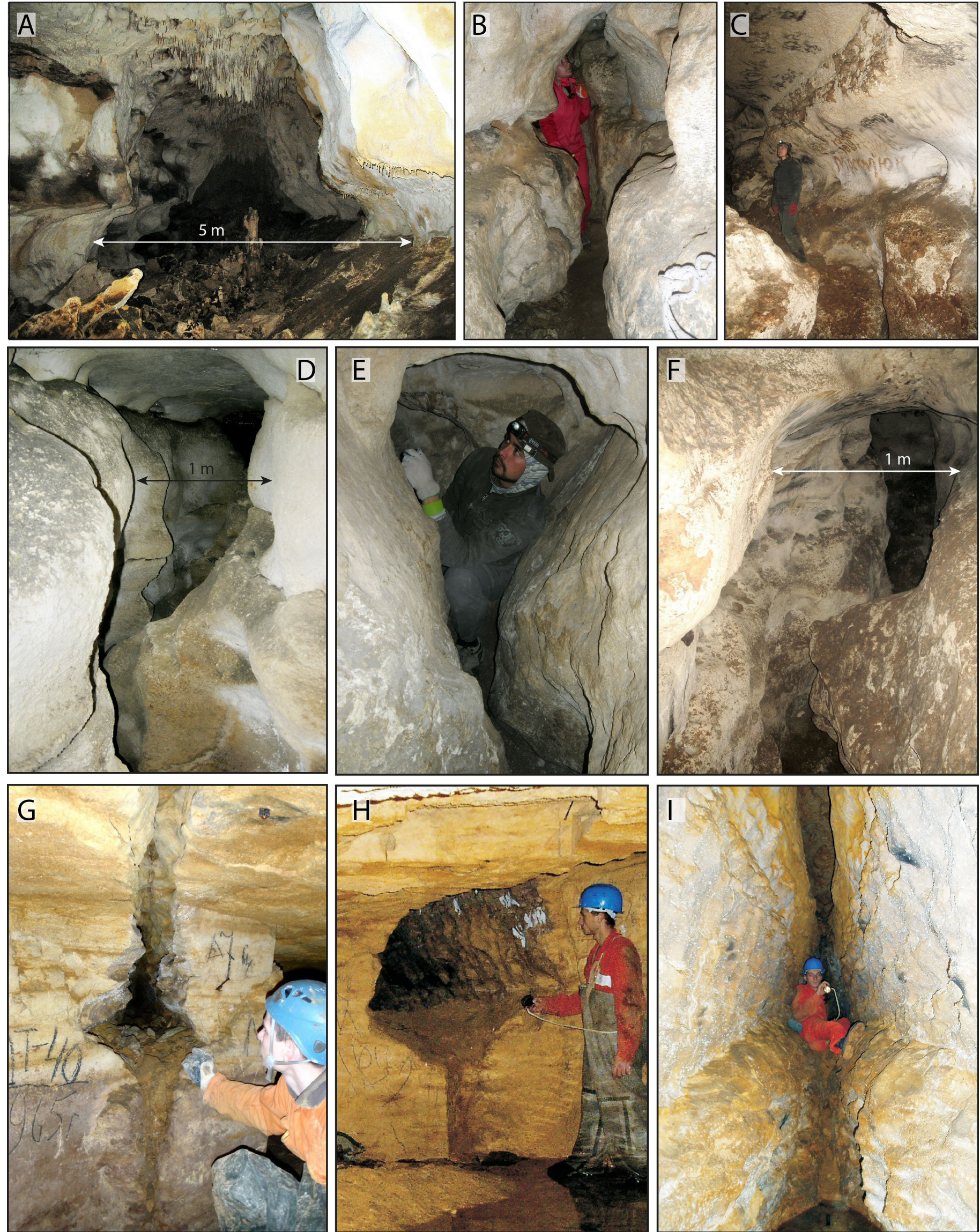

Fig. 6. Morphology of the widened parts of fracture-controlled conduits where they intersect with stratigraphy-controlled permeability structures. Photo A, B and D are from caves in Paleocene limestones (A and D - Tavrskaya Cave; B - Mangupskaya Cave). Photo C, E and $\mathrm{F}$ are from caves in Eocene limestones ( $\mathrm{C}$ and $\mathrm{F}$ - Zmeinaya Cave; $\mathrm{E}$ - Lisya Cave). Photo $\mathrm{G}$ through I are from caves in lower Pliocene limestones (the Odessa caves). Photo A shows the morphology of a master passage in Tavrskaya Cave (in the upper story) and photo D shows the rift-like passage morphology in the same cave (in the lower story). Photo $C$ and $F$ from Zmeinaya Cave are similarly related. For visualization of the spatial relationship between these elements see Fig. 4, A. 


\section{LATERAL WIDENING AND SIDE FEATURES IN FRACTURE-CONTROLLED CONDUITS The Odessa region}

In the Odessa region, caves occur in young porous lower Pliocene (Pontian) limestones, being confined to a particular interval in the middle part of the succession. All 68 caves documented in the region are karst conduits intercepted by extensive systems of underground limestone mines, locally called "catacombs", which total lengths is estimated to be over $2,500 \mathrm{~km}$. The caves have total length of about $7,150 \mathrm{~m}$, including 7 caves with individual lengths of over $300 \mathrm{~m}$ and two caves longer than 1 $\mathrm{km}$ (Pronin, 2009). Systematic survey of karst conduits has been performed only in certain limited areas (mine fields). Besides caves of human-passable dimensions, numerous sub-vertical karstified fractures (widened to a few centimeters or decimeters) are intercepted by adits. High density and maze character of adits in mine fields creates a unique situation that virtually all karst conduits are intercepted and documented within some fields to show a complete picture of their distribution in area (Fig. 5).

The outstanding feature of the Odessa caves is their complete lateral isolation and apparent irrelevance to the surface. Caves are fracture-controlled, single linear passages, or clusters of intersecting passages (the longest cave totals in 1,470 $\mathrm{m})$, blind-ended in every lateral direction. The basic morphology of conduits is represented by karstified fractures, which are "underdeveloped caves" (Fig. 6 G). They become caves where widened to the accessible dimensions (Fig. $6 \mathrm{H}-\mathrm{I}$ ). The widening occurred along a particular limestone layer so that oval or rhomb-like swells developed in the original fracture-like cross-sections. With respect to the major plane of the fracture-like passage, such widened intervals are laterally extended niches or notches. Sometimes notches cut into the walls deeper, creating expressed "wings" in cross-sections. In places, there are two levels of lateral notching. Small side bed-parallel channels stretching away from the master passages occur frequently in the apexes of notches, pinching out in a few meters (Fig. $7 \mathrm{H}$ ).

In passage cross-sections, lateral niches and notches can be symmetric in the sides, commonly cutting for $0.5-1.0 \mathrm{~m}$ into the walls (with respect to the passage axis), or asymmetric, with a notch on one side cutting deeper, for up to $2-5 \mathrm{~m}$.

A detailed morphogenetic analysis of the caves in the Odessa region has demonstrated their transverse hypogenic origin (Klimchouk et al., 2010). The cave passages are sub-vertical conduits that functioned according to the transverse speleogenesis model, i.e. conducting rising flow along the vertical extent of a fracture, across the limestone sequence. The lateral widening of the original fracture-like conduits is attributed to mixing corrosion due to interaction of the upwelling conduit waters and matrix waters drained from beds of enhanced permeability.

\section{The Inner Range of the Crimean fore-mountain}

In the Inner Range of the fore-mountain Crimea, caves occur in two distinct limestone beds of Eocene and Paleocene, separated by marly-clayey sediments. Besides innumerable grottos, niches, small cavities and solutionally-sculptured walls of karstified fractures exposed in limestone scarps due to their block-fall retreat, there are 30 known significant "true caves", i.e. human-enterable conduits oriented normal or oblique to the scarps, so that the integrity of cave space is preserved (in contrast to "unwalled caves", along which some most of the scarps have been formed; see next section). Caves are mainly linear in the plan view, strictly controlled by sub-vertical fractures. The longest documented cave in the Paleocene limestone is Tavrskaya Cave, a $507 \mathrm{~m}$ long system consisting of two parallel connected master passages. The longest cave in the Eocene limestones is $\mathrm{Zmeinaya}$ Cave, a single $310 \mathrm{~m}$ long passage. The conceptual model of hypogenic speleogenesis in the region is presented in Fig. 4, showing functional relationships of conduits occurred in different beds and also visualizing a mode of the exposure of hypogenic karst morphologies in the today's limestone scarps.

A prominent common feature of caves in both Eocene and Paleocene limestone beds is that their human-accessible passages are, in fact, intervals of sub-vertical karstified fractures widened along lines of intersection of the fracture conduits with beds and bedding planes of relatively high permeability (Fig. 6 A-F). Such stratigraphically controlled intervals, widened up to a few meters, have much narrower rift-like extensions downward, immediately below or an echelon, only partly accessible in places because of their smaller cross size and blockage, but also observable in the scarps outside. The widened intervals have laterally extended niches and notches in the walls. It is very common that in the apexes of such niches and notches there are variously shaped enclosed pockets, vugs, and small lateral conduits pinching out away from the master conduits (Fig. 7).

Another important feature of the overall cave morphology is that the rock surfaces in and above the widened interval (above the level of intersection of a fracture conduit with a lateral high permeability layer or a bedding plane) are characterized by abundance of convection features such as spherical convections niches (often stacked in vertical series), rising channels on hanging walls, ceiling channels and cupolas, whereas the walls in the rift-like lower sections have much less of these features. This suggests that natural convection pattern was induced or regenerated by mixing of the conduit and matrix waters to encompass the space above the major interval of the lateral inflow.

Cross-sectional shapes of the passages and distribution and dimensions of the above described side features often demonstrates an expressed asymmetry between the opposed walls, which is explained by the inequality of lateral inflow of the matrix waters from the sides to the conduit due to peculiarities of its position and orientation in the intrastratal flow field. The clear case of such asym- 

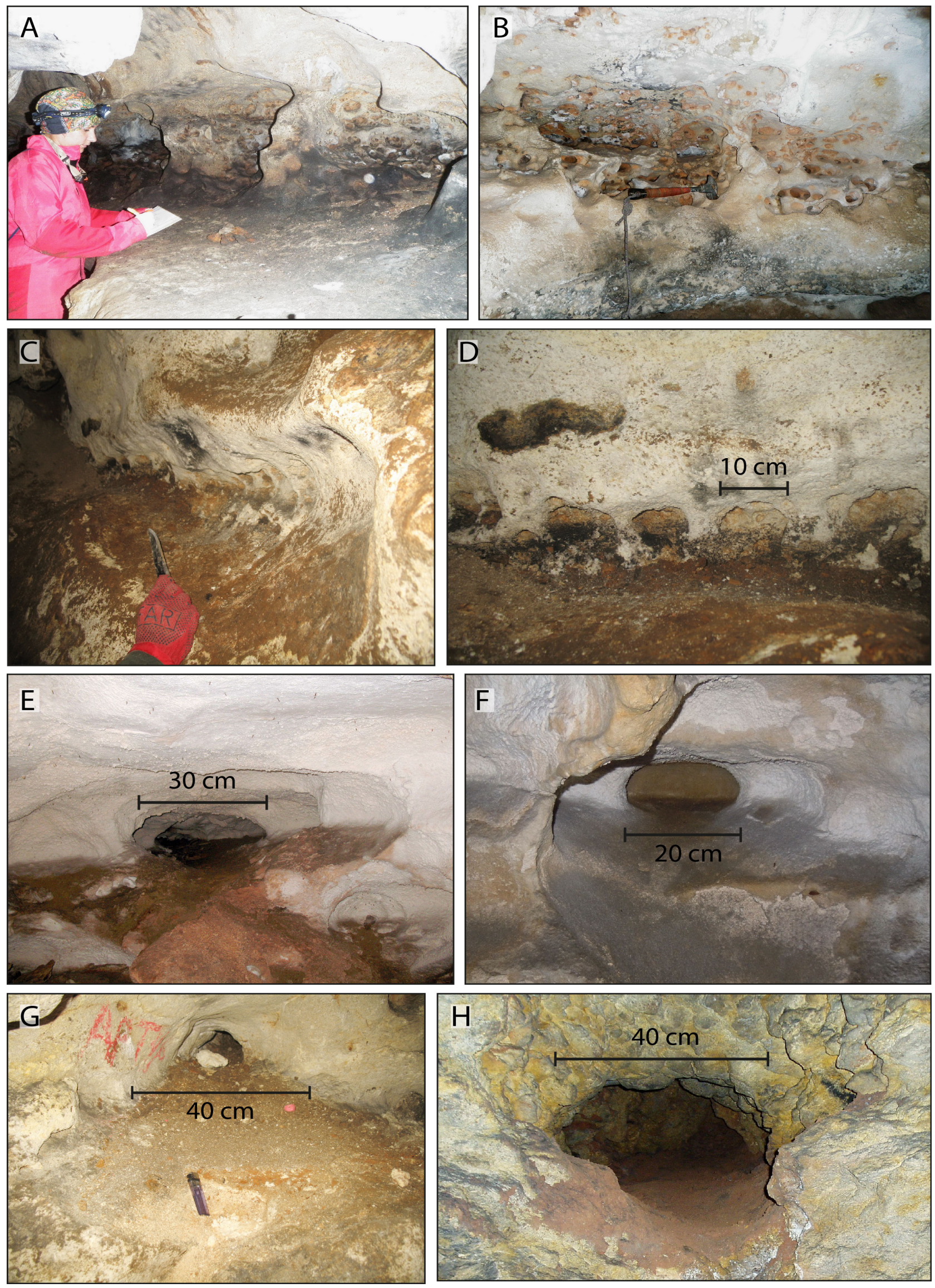

Fig. 7. Stratigraphically-controlled side niches, small conduits and caverns in fracture-controlled conduits. A and $C-$ laterally extensive side niches in Mangupskaya (A) and Zmeinaya (B) caves. B and D - front close-up views at the apexes of the niches shown in $\mathrm{A}$ and $\mathrm{C}$, showing various small cavernousity; $\mathrm{E}$ through $\mathrm{H}$ - lateral side conduits pinching out away from the master passages ( $E$ and $F$ - Tavrskaya Cave; G - Zmeinaya Cave; $\mathrm{H}$ - a cave in the Odessa region). A, B, E and F- caves in Paleocene limestones; C, D and G - caves in Eocene limestones; $\mathrm{H}$ - a cave in lower Pliocene limestones. 
metry is illustrated by the morphogenetic map of the Tavrskaya Cave (Fig. 8 A), where side niches and pinching conduits are much better developed along the northern contour of the cave field than along the southern contour. The inner walls of the master passages within the cave field have only few small shallow niches. This pattern of lateral side conduits surrounding a master fracture-controlled passage, commonly with the expressed asymmetry, can be found in caves of other regions; an instructive example is the Shamsham Cave in upper Cretaceous limestones of the Iranian Plateau, west Iran, shown in Fig. 8 B for comparison.

A comparison of the characteristics of the Odessa and Crimea caves clearly shows that in spite of some distinctions imposed by tectonic position and local structural and sedimentologic features, hypogenic caves in limestones of different age and of different degree of diagenetic maturity have some remarkable common features in their morphology.

\section{RELICT HYPOGENE KARST FEATURES IN LIMESTONE SCARPS (THE INNER RANGE OF THE CRIMEAN FORE-MOUNTAIN REGION)}

A remarkable feature of the Inner Range of the Crimean fore-mountain region is the abundance of grottoes, niches and various small cavities and vugs (spongework zones) in its extensive limestone scarps. Because of their prominent appearance and abun-

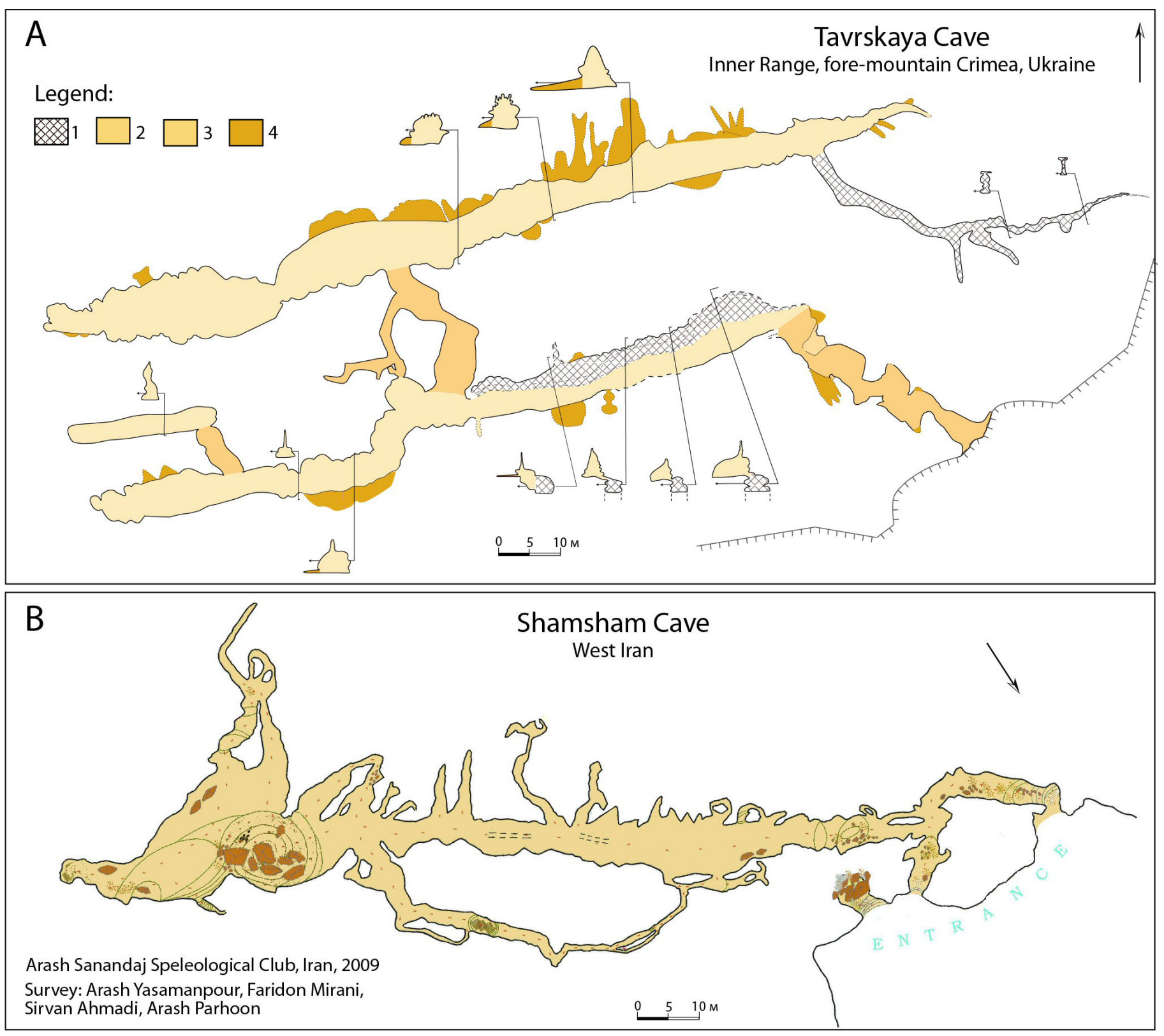

Fig. 8. A - Simplified morphogenetic map of the Tavrskaya Cave (Crimea, Ukraine) showing the main morphotypes of passages: 1 - fracturecontrolled rift-like passages in the lower story; 2 - fracture-controlled master passages in the upper story with abundant convection mesoforms; 3 - stratigraphy-controlled passages; 4 - stratigraphy-controlled side niches and conduits bordering the master passages. B - Map of the Shamsham Cave (Kordistan, west Iran) showing similar pattern. The master passage is a large, fracture-controlled passage. Side passages and niches are low, stratigraphy-controlled features (the map courtesy of the Arash Sanandaj Speleological Club, Iran). 

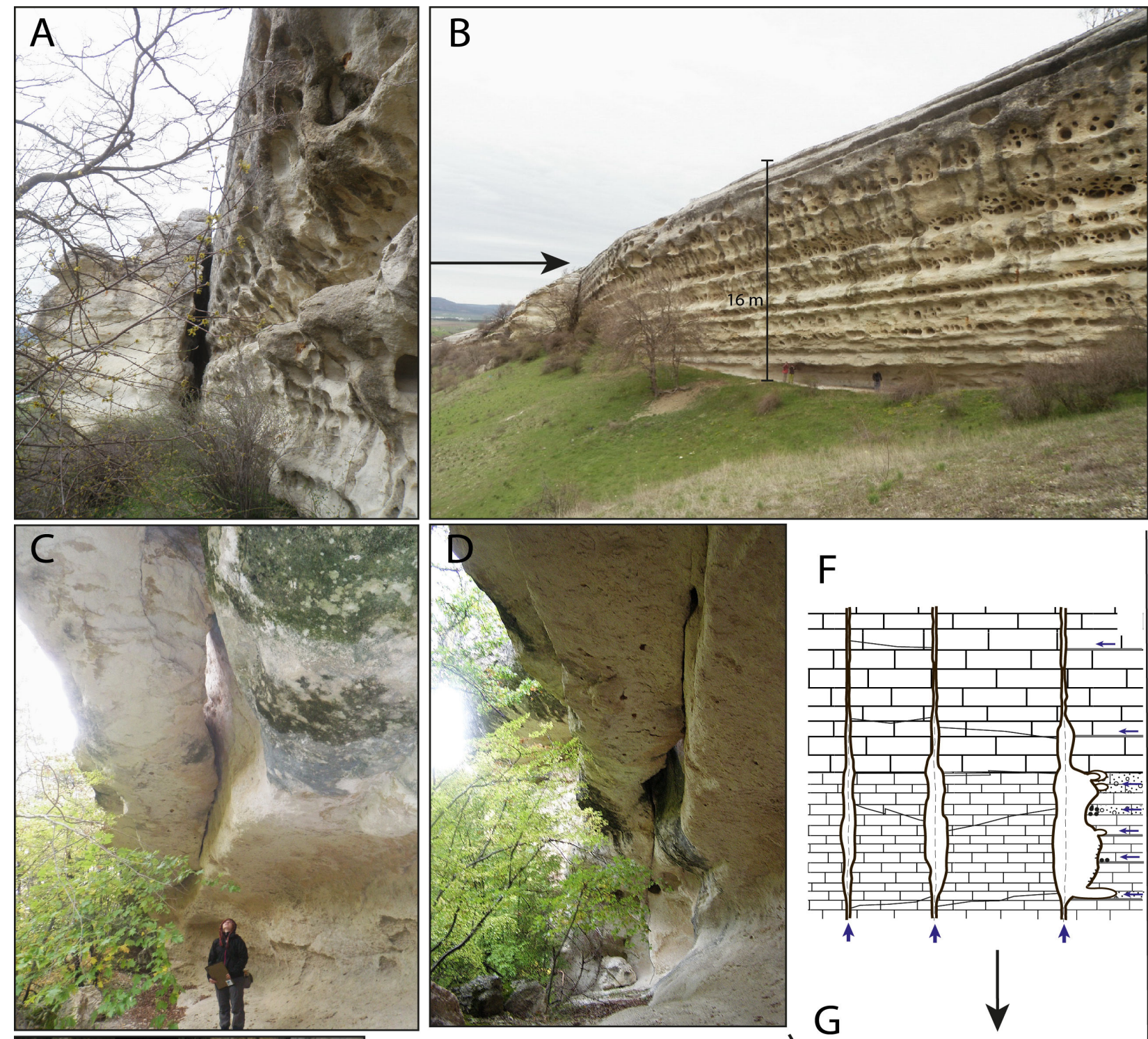

$\mathrm{F}$
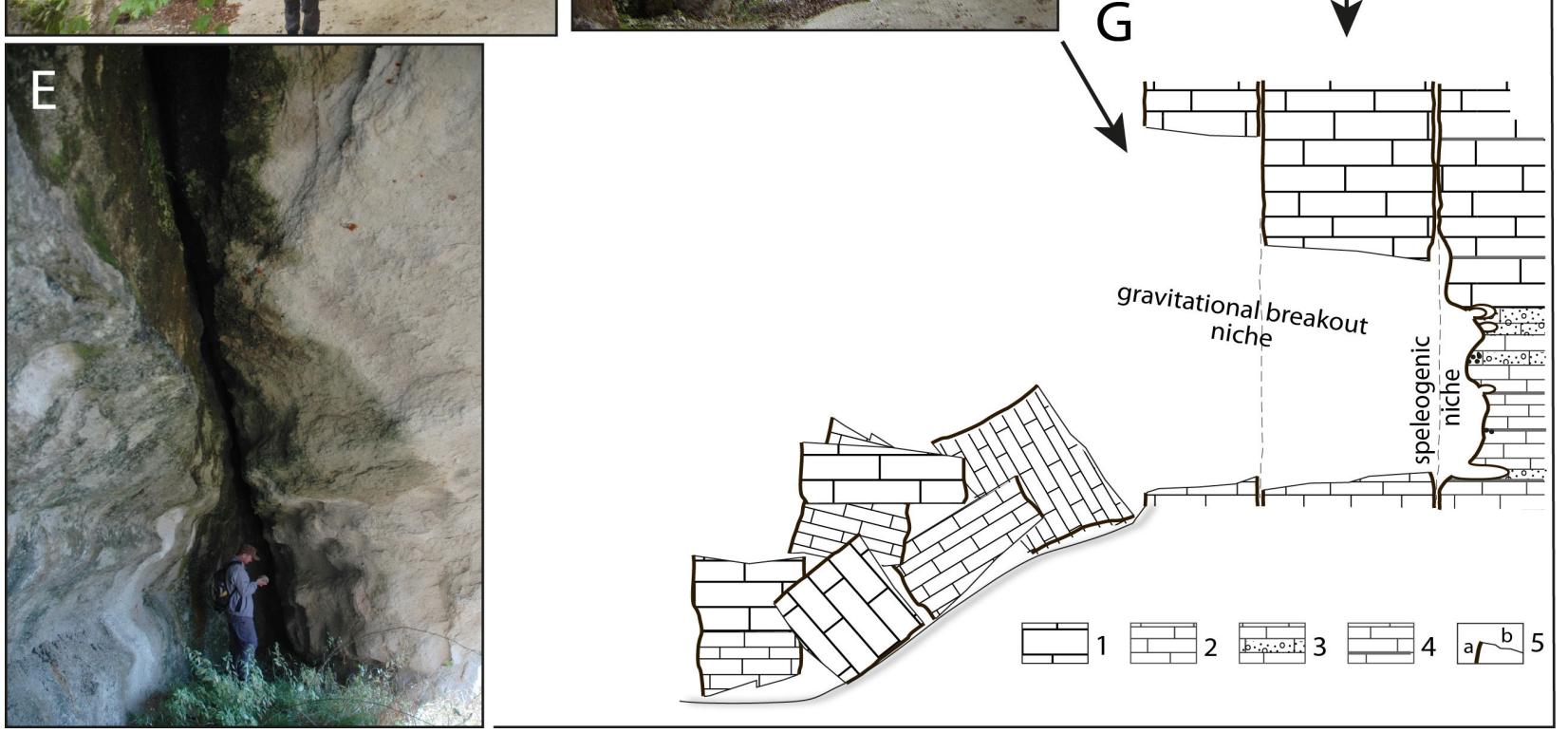

Fig. 9. Fracture-conduit control of the limestone scarp formation in the south-west part of the Inner Range. Photos A - E are the Eocene limestone scarps where only some sections of the fracture-conduits were exposed by the block breakout while other sections remained intact. The diagram $G$, directly matching to the situation on the photo $D$, visualizes the mechanism of the scarp formation through gravitational destruction of an original karstified zone $(F)$. Other photos illustrate similar situations in different locations. The keys to the diagrams: 1 - compact, coarsely-bedded limestone; 2 - non-compact, unevenly bedded limestone; 3 - layers of relatively higher matrix permeability; 4 - prominent permeable bedding planes; 5 - surfaces: a solutionally sculptured; $\mathrm{b}$ - gravitational breakout. Arrows in $\mathrm{F}$ indicate flow directions during speleogenesis. 
dance, grottoes and niches in the Inner Range have always attracted human attention and were extensively used in different pre-historic and historic times as dwellings, shelters, storehouses and religious sites. They were vaguely interpreted in the geomorphological literature as features created by "complex denudation", or external weathering, with supposed particular roles of deflation and desquamation (Dushevskiy, 1971; Klyukin, 2007; Blaga \& Popov, 2009). Their relations to karst features such as caves and spongework zones, as well as mechanisms of their specific morphogenesis, were not considered.

The terms "grottoes" and "niches" are vaguely defined and used in various meanings. In this paper, we use the term "grotto" to describe a cavity within a vaulted roof which is widely open to a scarp, quasiisometric in plan, with the opening being normally larger than the dimension normal to a scarp. A niche is a shallower hollow in a scarp, commonly laterally extensive along it, although shallow spherical hollows are also called niches.
Our recent studies provided ample and systematic evidences that grottoes and niches in limestone scarps of the Inner Range are remnants of morphologies of hypogenic cavities and fracture-controlled karst conduits, the walls of which are now exposed due to block-fall retreat of the scarp faces (Klimchouk et al., 2009; Klimchouk \& Tymokhina, 2011; Tymokhina et al., 2011). Various vugs and small lateral conduits in the exposed walls are features of a "vuggy-spongework halo" of the fracture-controlled conduits, the notion introduced and discussed in the following sections.

\section{The formation of scarps along fracture conduits}

Incision and further evolution of valleys into the limestone beds in the structural slope of the Eocene and Paleocene limestones was strongly guided by hypogenically karstified, 100-400 m wide linear zones of intense sub-vertical fracturing, with most of individual fracture conduits oriented along the strike of the zone (Tymokhina et al., 2011). The limestone beds form steep to vertical scarps in the valley slopes,

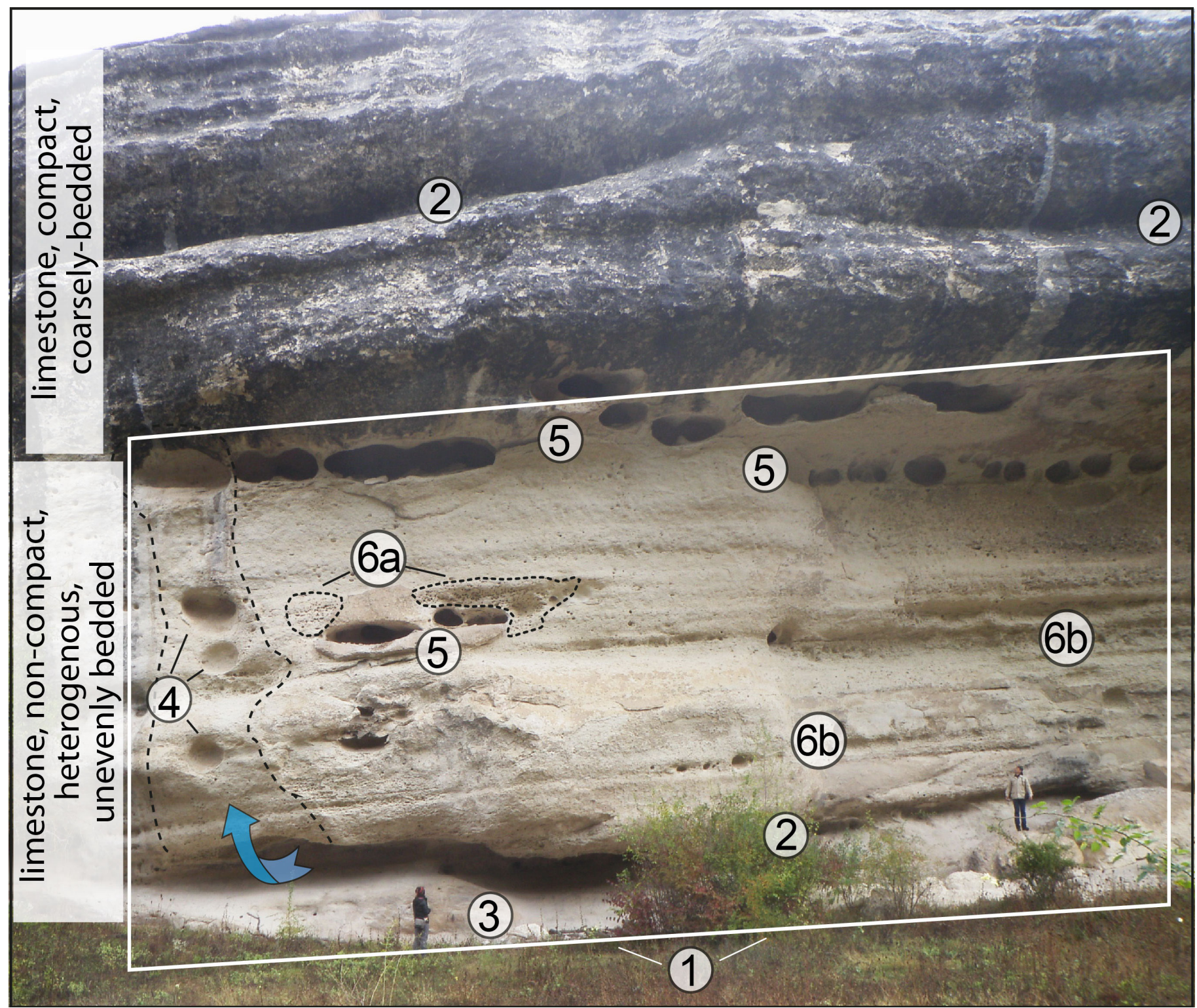

Fig. 10. Karst features in a scarp of Eocene limestones in the south-west part of the Inner Range (the Krasny Mak locality). The scarp is exposed by the gravitational breakdown along a sub-vertical karstified fracture conduit, which major plane is shown by the frame. The exposure mechanism is illustrated in Fig. 9. Forms indicated by numbers in circles are explained in the text. 

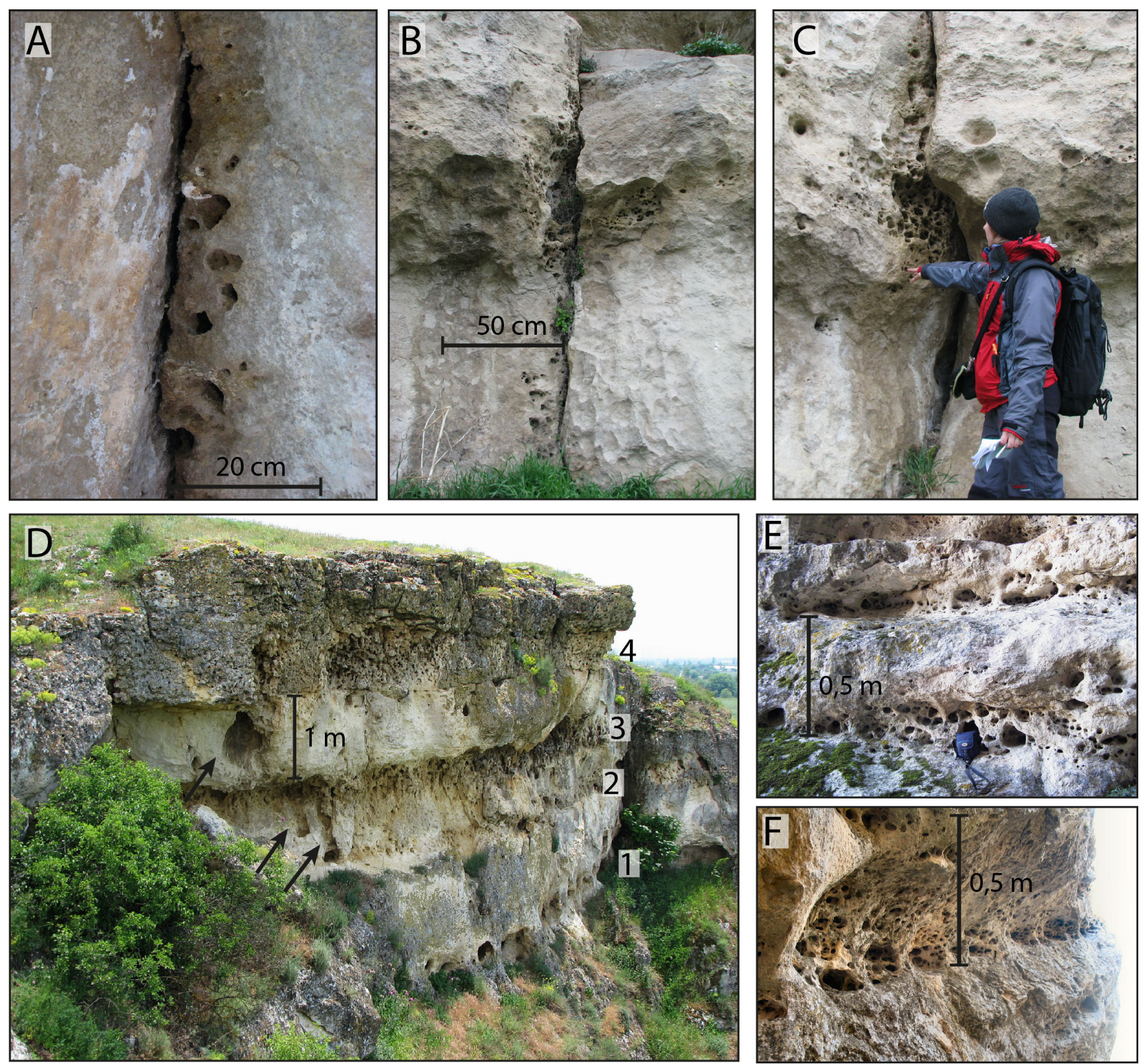

Fig. 11. Spongework zones fringing fracture-controlled conduits as displayed in Eocene limestone scarps of the Inner Range: A-C - clustered spongework zones (note distinct asymmetry in their occurrence in different sides of the conduits); D-F - stratigraphy-controlled spongework zones. In photo $D$ four distinct zones are recognizable (indicated by numbers). A surface-exposed scarp in photos $E$ and $F$ is a direct continuation of the master passage of the Zmeinaya Cave, where similar spongework intervals are observed in the respective intervals.

which retreat through detachment and fall of rock blocks. This process exposes new karstified fractures and cavities that remained in marginal parts of the karstified zones.

The hypogenic karstic origin of the morphosculptures in the limestone scarps is strongly corroborated by the following observations:

- The hollow and vuggy morphologies exposed in the scarps closely match those observed in the walls of hypogenic caves;

- Among hollow and vuggy features in the scarps many morphs clearly indicative of natural convection circulation of fluids, which could not form by weathering in the present exposed settings;
- Abundant hollow and vuggy morphologies are observed in relatively freshly exposed sub-vertical scarps, with fallen blocks and boulders on the foot slopes beneath bearing similar forms, whereas gravitationally stabilized, denuded exposures display only degraded sleek features if any.

The direct evidences of the fracture-conduit control of the scarp formation are found in a number of places where only some sections of the conduits were disclosed by the block fallout to form a new line of the exposed escarp, whereas some terminal sections remained intact (Fig. 9). The photos clearly illustrate that laterally extended niches, stratiform cavities and vuggs in the exposed scarps are in fact the direct con- 
tinuations of morphologies in the conduit walls, but not features formed by external weathering agents.

\section{Hollow and vuggy features in limestone scarps}

The wide occurrence in the Inner Range of limestone scarps formed through the recent exposure of hypogenic fracture-controlled conduits provides outstanding possibilities to directly examine details of the original solutional morphology of these conduits. There is great variety of hollow and vuggy morphologies displayed in their exposed walls, as illustrated in Figs. $9-11$. Most of these features are representations of the interaction between rising conduits flow and lateral matrix flow. This is suggested by two key observations:

- Most of hollow and vuggy features display distinct stratigraphic control.

- Various vuggy forms and small side conduits do not extend for more than $0.5-2 \mathrm{~m}$ into the rock from the face of fracture conduits; instead, they form a vuggy-spongework halo around the conduits along certain intervals and bedding planes or, less frequent, in clusters. This is proven by numerous observations in natural and artificial cuts and splits.

The appearance and distribution of hollow and vuggy features in the scarps varies in different sectors of the Inner Range depending on the stratigraphic position and orientation of exposed faces, rock's texture and structure and local paleohydrogeological conditions. These features can be classified as follows:

1. The morphology of the fracture conduit wall that constitutes a scarp face (1 in Fig. 10) is a complex assemblage of hollows of the conduit wall surface itself, such as niches, notches and pockets, and of openings of various cavities of the vuggy-spongework halo.

2. Laterally extended niches and notches that correspond to widened intervals of the original conduits (2 in Fig. 10; see also Fig. 6, A-D in Fig. 7 and A-E in Fig. 9).

3. Locally more deepened sections of niches ( 3 in Fig. $10)$, or isolated chambers (see next section), that appear as grottoes in the scarps.

4. Half-spherical convection niches and pockets (4 in Fig. 10). They may occur separately, but are commonly organized into vertically stacked series corresponding to areas of preferential rising flow along the original fracture conduit (as indicated by a chain line in Fig. 10). Such areas are sometimes represented as rising wall channels. The arrow in this figure indicates the rise of a convection current from a niche to the vertical plane of the fracture conduit.

5. Isometric or oval cavities of decimetric size, sometimes merged, commonly organized in stratiform series (5 in Fig. 10; seen also in Fig. 9 B).

6. Spongework zones - areas or intervals of densely packed, variously interconnected irregular vugs of centimetric sizes forming spongework patterns. Such zones can be stratigraphy-controlled (6a in Fig. 10; see also D, E and F in Fig. 11) or irregular clusters (6a; see also A-C in Fig. 11). In Fig.
11, photos A through B clearly demonstrate that the spongework zones form an asymmetric halo around fracture conduits oriented normal to the scarp face. The stratigraphy-controlled spongework zones in photos D through F form a halo too, although this is not that obvious as the fracture conduit walls are the scarp faces on these photographs.

7. Lateral conduits of decimetric cross-sectional sizes stretching normal to the scarp face and pinching out in a few meters away of it. They are similar to the side conduits observed in caves.

8. Transverse sub-vertical tubular or irregularly shaped conduits of decimetric cross-sectional sizes that connect adjacent stratigraphy-controlled spongework zones across less pervious layers. Such conduits can be entirely internal within the rock (i.e. not opened to the major fracture conduit) or partly open to the fracture plane. In photo D in Fig. 11 conduits of this type (pointed by arrows) connect the lateral spongework zones 2-3 and 3-4.

In this classification, categories 2,3 and 4 are variously shaped swells of the major fracture conduit itself (morphological features of its walls), but categories 5,6 and 7 are the components of the conduit's vuggy-spongework halo.

Similarly to the features observed in caves, hollow and vuggy features in limestone scarps often display distinct asymmetry between differently oriented scarp faces formed due to peculiarities of positions and orientations of the original fracture-controlled conduits in the intrastratal matrix flow field.

\section{Isolated chambers giving rise to grottoes and niches}

Photos in Fig. 12 illustrate abundance and the variety of grottoes and niches exposed in limestone scarps in the Inner Range. They are relicts of hypogenic cavities in the karstified fractured zones exploited by incised valleys. This origin for grottoes and niches is strongly corroborated by the following observations:

- They are associated with the sub-vertical fracture conduits (E through I in Fig. 12);

- Their occurrence on scarps is stratigraphically controlled (all photos in Fig. 12);

- They contain enclosed meso-forms indicative of natural convection circulation cells, which could be formed only in the water-saturated, sluggish dynamic media, i.e. in hypogene settings (B, F and $\mathrm{H}-\mathrm{K}$ in Fig. 12).

Some grottoes are sections of niches at the sides of former fracture conduits (i.e. present scarp faces) particularly enlarged due to locally enhanced matrix water inflow from a more pervious layer to the conduit. Such grottoes may not have guiding master fractures normal to the scarp. However, most of grottoes do have such fractures (photos E through I in Fig 12), which means that they were formed where the junction of two vertical fracture sets, one of the main trend (along which the scarp was formed), and another one normal or oblique to the scarp, intersects with layers of relatively higher permeability. This is the dominant mode of the formation of iso- 

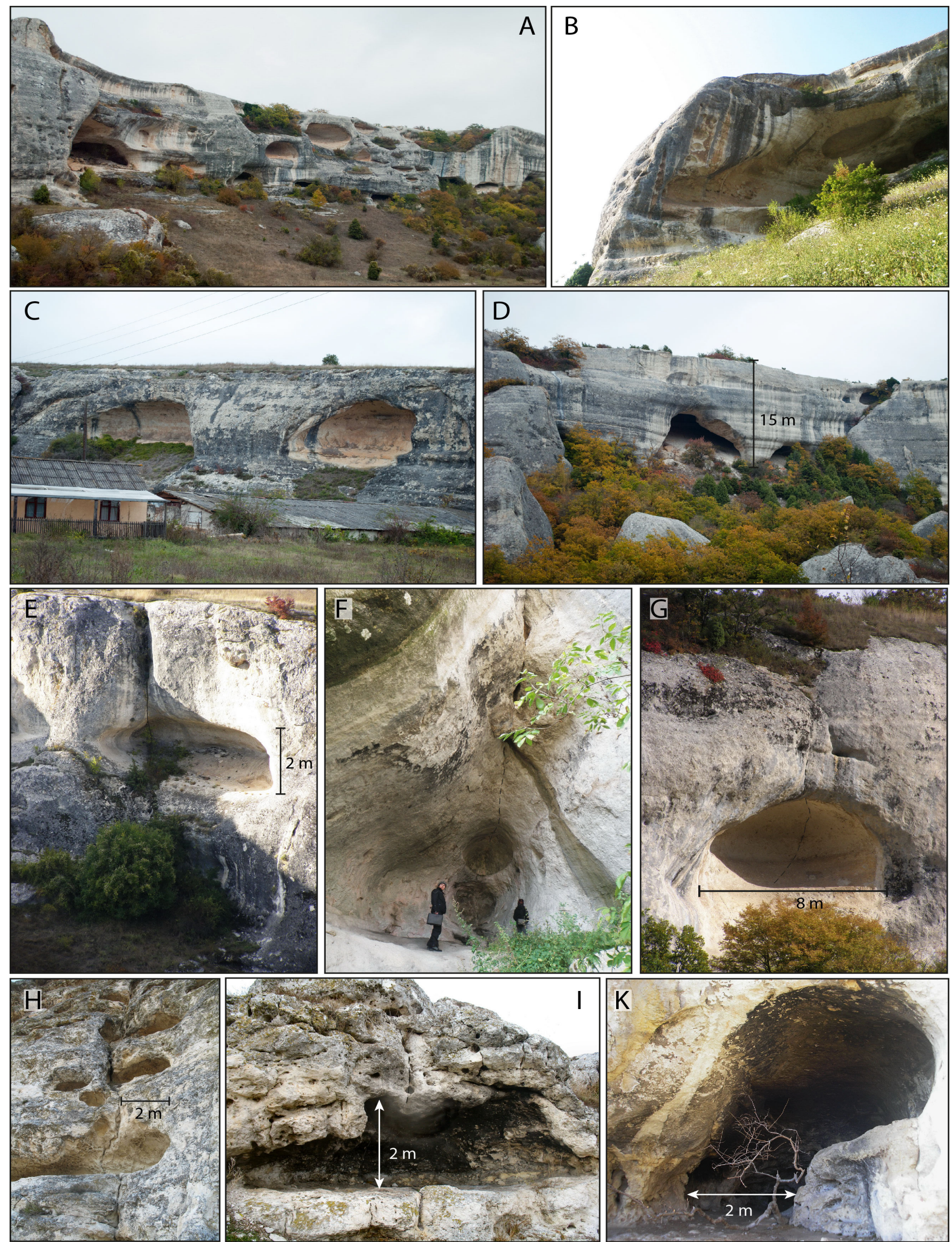

Fig. 12. Grottoes and niches as displayed in the limestone scarps of the Inner Range. Photos B, F, H, I and K show the meso-forms in the grottoes, characteristic for dissolution by natural convection currents. Photos $\mathrm{E}$ through I demonstrate the control by transverse fracture conduit (relative to the dominant fracture sets along which the scarp faces are formed). Photo K show a cavern that rises from the major highly permeable interval at the bottom of the limestone bed, along the contact between upper Cretaceous marls and Paleocene limestones. All other photos show the scarps in Eocene limestones. 
lated chambers that are represented as significant grottoes in the exposed limestone scarps (see Fig. 2 A for a conceptual model).

\section{DISCUSSION AND CONCLUSIONS}

The field examples presented in the preceding sections strongly suggest that in hypogene karst settings the interaction between deeply derived fractureconduit flow and intrastratal matrix flow, localized at intervals where respective permeability structures intersect, results in expressed morphological effects. These effects include lateral widening of fracture-like sub-vertical conduits within the interaction intervals (formation of lateral notches and niches) and the development of side bedding-parallel conduits, pockets and vuggy-spongework zones. Natural convection circulation in the conduit space, invoked by interaction of the two flow systems, spreads the morphological effects above the interaction interval. Quite spacious lateral swelling can form in this way. Where the interaction of the two flow systems is particularly strongly localized, such as along junctions of two vertical fracture sets, the resultant morphological effect can take a form of isolated chambers. The principal dissolution mechanism for these morphological effects is the mixing corrosion, i.e. the renewal of solutional aggressiveness due to mixing of the waters of contrasting chemistry. The described effects match well to the conceptual models visualized in Figs. 1 and 2.

The field studies demonstrate that the speleogenetic effects of the interaction of deeply derived fracture-conduit flow and intrastratal matrix flow in hypogene karst settings are significant and wide spread, being represented throughout large regions. A comparison of karst features in different regions and rock formations within the Prichernomorsky basin clearly shows that in spite of some distinctions imposed by local structural, sedimentological and paleo-hydrogeological peculiarities, speleoforms in limestones of different age and of different degree of diagenetic maturity demonstrate remarkable similarities.

In the Inner Range of the Crimean fore-mountains, the wide occurrence of limestone scarps, formed through the recent exposure of hypogenic fracturecontrolled conduits, provides outstanding possibilities to directly examine details of the original hypogenic karst porosity. The variety of hollow and vuggy morphologies displayed in exposed walls of the conduits is due to different modes of the conduit/matrix flow interaction according to local peculiar features of respective permeability systems and paleo-hydrogeological conditions. The variety of speleogenetic features can be broadly grouped into two categories: 1) variously shaped swells in the major fracture conduit itself (morphological features of its walls - niches, notches and pockets), and 2) features of the vuggyspongework halo surrounding the conduit. This halo includes clustered and stratiform cavities, spongework zones and lateral side conduits.

The presence of sustained stratigraphy-controlled widened intervals along the lateral stretch of fracturelike conduits in hypogenic systems gives a misleading impression of lateral cave passages. Nevertheless, such passages are sub-vertical conduits that functioned according to the transverse speleogenesis model, i.e. conducting rising flow across the vertical extent of a fracture and the rock sequence. The apparent passages are, in fact, laterally extended swellings in transverse fracture-type conduits, but not lateral conduits in the functional sense as they may seem to be. Based on cursory observations in many caves in different regions around the world, we suggest that this interpretation can have wide application.

The development of the vuggy-spongework halo around fracture-controlled hypogenic karst conduits is a distinct and important phenomenon in the study region, which may also be wide spread in other regions, particularly in eogenetic carbonates.

The hypogene speleogenesis features due to conduit/matrix flow interaction, especially the halo forms, often demonstrate distinct asymmetry between opposite walls of the conduits, which is explained by inequality of lateral inflow of the matrix waters from the sides to the conduit due to peculiarities of its position and orientation in the intrastratal matrix flow field. Potentially, this phenomenon could be used to develop a methodology of reconstructing paleo-flow patterns from studying spatially defined distribution of conduits and their halo features.

Recognition of the vuggy-spongework halo around fracture-controlled conduits can have numerous implications in karst hydrogeology, flow models and reservoir studies. Just to name a few:

- Interception of highly permeable stratiform vuggyspongework zones by a borehole does not necessarily imply that these zones are laterally isotropic and extensive, as they may represent the halo of a vertical fracture-like conduit nearby;

- The presence of this halo should be taken into account in estimating the conduit porosity;

- The presence of the vuggy-spongework halo increases the effective surface of the conduit and roughness of the conduit walls. It can contribute significantly to hydrodynamic dispersion, and to retardation and smearing of hydraulic signals in fracture-conduit systems.

These and other possible implications should be further elaborated.

\section{ACKNOWLEDGEMENTS}

This study was partially supported by a grant 0110 U002248 of the Ministry of Education and Science of Ukraine. The authors thank two anonymous reviewers for their comments and useful suggestions that improved the paper.

\section{REFERENCES}

Barenblatt G., Zheltov Y. \& Kochina I., 1960 - On basic concepts of theory of homogeneous fluid flow in fissurized rock. Applied Mathematics \& Mechanics, 24: 852-864.

Bauer S., Liedl R. \& Sauter M., 2003 - Modeling of karst aquifer genesis: influence of exchange flow. Water Resources Research, 39: 1285. http:/ /dx.doi.org/10.1029/2003WR002218 
Blaga N.N. \& Popov A.V., 2009 - Some aspects of morphogenesis of grottoes and rock shelters of the Inner Range of the Crimean Mountains. Kultura narodov Prichernomorja. Simferopol, 155: 7-9. (Russian).

Bogli A., 1964 - Mischungskorrosion - ein Beitrag zur Verkarstungsproblem. Erdkunde, 18: 83-92. http://dx.doi.org/10.3112/erdkunde.1964.02.02

Borevsky B.V., Samsonov B.G. \& Yazvin L.S., 1973 - Methods of determination of parameters of aquifers from pumping data. Nedra, Moscow, 326 p. (Russian).

Borevsky B.V., Hordikayen M.A. \& Yazvin L.C., 1976 - Prospection and evaluation of available groundwater reserves in fracture-karstic aquifers. Nedra, Moscow, 248 p. (Russian).

Budd D.A. \& Vacher H.L., 2004 - Matrix permeability of the confined Floridan Aquifer, Florida, USA. Hydrogeology Journal, 12: 531-549. http://dx.doi.org/10.1007/s10040-004-0341-5

Choquette P.W. \& Pray L.C., 1970 - Geological nomenclature and classification of porosity in sedimentary carbonates. American Association of Petroleum Geologists Bulletin, 54: 207-250.

Clemens T., Hùckinghaus D., Sauter M., Liedl R. \& Teutsch G., 1996 - A combined continuum and discrete network reactive transport model for the simulation of karst development. Calibration and Reliability in Groundwater Modeling. Proceedings of the ModelCARE 96 Conference held at Golden, Colorado, September 1996, 237: 307-316.

Cunningham K.J., Renken R.A., Wacker M.A., Zygnerski M.R., Robinson E., Shapiro A.M. \& Wingard G.L., 2006 - Application of carbonate cyclostratigraphy and borehole geophysics to delineate porosity and preferential flow in the karst limestone of the Biscayne aquifer, SE Florida. In: Harmon R.S. \& Wicks C. (Eds). - Perspectives on karst geomorphology, hydrology, and geochemistry - A tribute volume to Derek C. Ford and William $B$. White. Geological Society of America Special Paper 404: 191-208.

Dreybrodt W., Gabrovšek F. \& Romanov D., 2005 Processes of speleogenesis: a modeling approach. Postojna-Ljubljana, $375 \mathrm{p}$.

Dushevskiy V.P., 1971 - On the development of the surface karst forms of the Piedmont Crimea. In: Problemu geografiyi Kryma. Simferopol: 21. (Russian).

Eichhubl P. \& Boles J.R., 2011 - Focused fluid flow along faults in the Monterey Formation, coastal California. Geological Society of America Bulletin 2000, 112: 1667-1679.

http://dx.doi.org/10.1130/00167606(2000) $112<1667:$ FFFAFI $>2.0 . \mathrm{CO} ; 2$

Florea L.J., 2006 - The Karst of West-Central Florida. Ph.D. Diss., University of South Florida.

Florea L.J. \& Vacher H.L., 2007 - Eogenetic Karst Hydrology: Insights from the 2004 Hurricanes, Peninsular Florida. Ground Water, 45 (4): 439446.

http://dx.doi.org/10.1111/j.1745-6584.2007.00309.x
Gorbach L.P., 1964 - Paleogeography of the Mesozoic and structural-tectonic regionalization of Crimea as a base for compiling maps of economic resources. Report of Investigation. Simferopol, 227 p. (Russian).

Groves C. G. \& Howard A.D., 1994. Early development of karst systems. 1. Preferential flow path enlargement under laminar flow. Water Resources Research 30: 2837-2846. http://dx.doi.org/10.1029/94WR01303

Hovorka S.D., Mace R.E. \& Collins E.W., 1998 Permeability structure of the Edwards Aquifer, South Texas-implications for aquifer management. Bureau of Economic Geology, The University of Texas at Austin, Austin, TX, Reports of Investigation: $250 \mathrm{p}$.

James N.P. \& Choquette P.W., 1984 - Diagenesis (9). Limestones - the meteoric diagenetic environment. Geoscience Canada, 11: 161-194.

Kaufmann G. \& Braun J., 1999 - Karst aquifer evolution in fractured rocks. Water Resources Research, 3223, 3238.

Klimchouk A.B. \& Ford D.C., 2000a - Types of karst and evolution of hydrogeologic settings. In: Klimchouk A.B., Ford D.C., Palmer A. \& Dreybrodt W. (Eds). - Speleogenesis: Evolution of karst aquifers. Huntsville: National Speleological Society: 45-53.

Klimchouk A.B. \& Ford D.C., 2000b - Lithological and structural controls of dissolutional cave development. In: Klimchouk A.B., Ford D.C., Palmer A. \& Dreybrodt W. (Eds). - Speleogenesis: Evolution of karst aquifers. Huntsville: National Speleological Society: 54-64.

Klimchouk A.B., Tymokhina E.I. \& Amelichev G.N., 2009 - Hypogene Speleogenesis in the Piedmont Crimea Range. In: Klimchouk A. \& Ford D. (Eds). Hypogene Speleogenesis and Karst Hydrogeology of Artesian Basins, UISK Special Paper 1, Simferopol, Ukraine: 159-171.

Klimchouk A.B., Pronin K.K. \& Tymokhina E.I., 2010 Speleogenesis in the Pontian limestones of Odessa. Speleology and Karstology, 5: 76-93. (Russian).

Klimchouk A.B. \& Tymokhina E.I., 2011 Morphogenetic analysis of Taurskaya Cave (Inner Range of the Piedmont Crimea). Speleology and Karstology, 6: 36-52. (Russian).

Klimchouk A.B., Timokhina E.I. , Amelichev G.N., 2011a - Hypogene Speleogenesis in the Cenozoic Carbonates of the Prichernomorsky Artesian Basin (north Black Sea Region). Speleogenesis and Evolution of Karst Aquifers, 11: 48-51 http://www.speleogenesis.info/content/ ?vmode $=$ issue \&issue $=11$

Klimchouk A.B., Tymokhina E.I., Amelichev G.N., Dublyansky Yu.V. \& Staubwasser M., 2011b - U/Th dating of speleothem of karst cavities in the south-west part of the Inner Range of the Mountainous Crimea and determination of the age of relief and denudation rates. Speleology and Karstology, 7: 29-39. (Russian). 
Klyukin A.A., 2007 - Exogeodynamics. Simferopol: 320 p. (Russian).

Laptev F.F., 1939 - Aggressive action of waters on the carbonate rocks, gypsum and concrete. MoscowLeningrad, 120 p. (Russian).

Liedl R., Sauter M. \& Hückinghaus D., 2003 Simulation of the development of karst aquifers using a coupled continuum pipe flow model. Water Resources Research, 39: 1057. http://dx.doi.org/10.1029/2001WR001206

Lucia F. J., 1995 - Lower Paleozoic cavern development, collapse, and dolomitization, Franklin Mountains, El Paso, Texas. In: Budd D. A., Saller A. H. \& Harris P. M. (Eds). - Unconformities and porosity in carbonate strata. American Association of Petroleum Geologists, AAPG Memoir, 63: 279300.

Lygina E.A., 2010 - The Danian and Eocene carbonate platforms of Crimea: structure and conditions of formation. PhD thesis. Moscow: Moscow univ., 25 p. (Russian).

Martin J. B. \& Dean R.W., 2001 - Exchange of water between conduits and matrix in the Floridan aquifer. Chemical Geology, 179: 145-165. http://dx.doi.org/10.1016/S0009-2541(01)00320-5

Moore P.J., Martin J.B., Screaton E.J. \& Neuhoff P.S., 2010 - Conduit enlargement in an eogenetic karst aquifer. Journal of Hydrology, 393: 143155.

http://dx.doi.org/10.1016/j.jhydrol.2010.08.008

Palmer A.N., 1991 - Origin and morphology of limestone caves. Geological Society of America Bulletin, 103: 1-21.

http://dx.doi.org/10.1130/0016-7606 (1991) $103<0001$ :OAMOLC $>2.3 . \mathrm{CO} ; 2$

Pronin K., 2009 - Natural caves of PrichernomorskoAzouskaja and Moldavsko-Podolskaja karst regions. Simferopol-Odessa, 130 p. (Russian).

Romanov D., Gabrovsek F. \& Dreybrodt W., 2002 - Interaction of fracture and conduit flow in the evolution of karst aquifers. In: Hydrogeology and Biology of Post-Paleozoic Carbonate Aquifers. Proceedings of the symposium Karst Frontiers: Florida and Related Environments March 6 through 10, 2002, Gainesville, Florida: 38-43.
Sauter M., 1993 - Double porosity models in karstified limestone aquifers: field validation and data provision. In: Hydrogeological Processes in Karst Terranes. Proceedings of the Antalya Symposium and Field Seminar, October 1990. IAHS Publ. no. 207: 261-279.

Sauter M. \& Liedl R., 2000 - Modeling Karst Aquifer Genesis Using a Coupled Continuum-Pipe Flow Model. In: Klimchouk A.B., Ford D.C., Palmer A. \& Dreybrodt W. (Eds). - Speleogenesis: Evolution of karst aquifers. Huntsville: National Speleological Society: 212-219.

Shoemaker W.B., Kuniansky E.L., Birk S., Bauer S. \& Swain E.D., 2008 - Documentation of a Conduit Flow Process (CFP) for MODFLOW-2005: U.S. Geological Survey Techniques and Methods 6-A24.

Sholle P.A., Bebout D.G. \& Moore C.H. (eds)., 1983 Carbonate Depositional Environments. Memoir 33, American Association of Petroleum Geologists. Tulsa, OK, $761 \mathrm{pp}$.

Tymokhina E.I., Klimchouk A.B. \& Amelichev G.N., 2011 - Geomorphology and speleogenesis of the extreme south-west part of the Eocene cuesta of the Inner Range of the Mountainous Crimea. Speleology and Karstology, 7: 40-51. (Russian).

Vacher H.L. \& Mylroie J.E., 2002 - Eogenetic karst from the perspective of an equivalent porous medium. Carbonates and Evaporites, 17 (2): 182-196. http:/ /dx.doi.org/10.1007/BF03176484

Yudin V.V., 2009 - Geological map of Mountain and Piedmont Crimea. 1:200000. Simferopol, Soyzkarta. (Russian).

Worthington S.R.H., 1999 - A comprehensive strategy for understanding flow in carbonate aquifers. In: Palmer A.N., Palmer M.V. \& Sasowsky I.D. (eds). - Karst Modeling. Special Publication 5. Charles Town, West Virginia: Karst Waters Institute: 30-37.

Worthington S.R.H., Ford D.C. \& Beddows P.A., 2000 - Porosity and Permeability Enhancement in Unconfined Carbonate Aquifers as a Result of Solution. In: Klimchouk A.B., Ford D.C., Palmer A. \& Dreybrodt W. (Eds). - Speleogenesis: Evolution of karst aquifers. Huntsville: National Speleological Society: 422-432. 